\title{
Groundwater quality in a semi-arid region of India: Suitability for drinking, agriculture and fluoride exposure risk
}

\author{
Tirumalesh Keesari ${ }^{1, *}{ }^{*}$, Uday Kumar Sinha ${ }^{1}$, Pradeep Kamaraj $^{2}$ \\ and Diana Anoubam Sharma ${ }^{3}$ \\ ${ }^{1}$ Isotope and Radiation Application Division, Bhabha Atomic Research Centre, Mumbai 400 085 , India. \\ ${ }^{2}$ Department of Earth Sciences, Annamalai University, Annamalai Nagar, Chidambaram 608 002, TN, India. \\ ${ }^{3}$ Department of Environment Studies, Panjab University, Chandigarh 160 014, India. \\ *Corresponding author.e-mail: tirumal@barc.gov.in
}

MS received 6 November 2017; revised 16 March 2018; accepted 26 April 2018;

published online 19 January 2019

Fluoride exposure through consumption of drinking water was studied in a heavily industrialised area and suitable measures were suggested to control the fluorosis risk to residents. Groundwater quality conforms to World Health Organization (WHO) criterion for drinking except for fluoride and is also suitable for irrigation. Fluoride concentration ranges from 0.1 to $4.4 \mathrm{mg} / \mathrm{l}$ and $39 \%$ of the total samples measured were found to be contaminated as per WHO limits $(1.5 \mathrm{mg} / \mathrm{l})$. The fluoride intake through drinking water was calculated to be $0.10 \mathrm{mg} / \mathrm{kg} / \mathrm{d}$ for infants, $0.09 \mathrm{mg} / \mathrm{kg} / \mathrm{d}$ for children and $0.05 \mathrm{mg} / \mathrm{kg} / \mathrm{d}$ for adults with a corresponding exposure dose exceeding 2.1, 1.9 and 1.1 times for infants, children and adults, respectively, compared to the minimum risk value of $0.05 \mathrm{mg} / \mathrm{kg} / \mathrm{d}$. The fluorosis risk map indicates that with a few exceptions of some western and northwestern parts, the entire study area is prone to fluorosis and the highest being in the south central part. The fluoride exposure dose suggests the risk of mottled enamel among residents if untreated groundwater is provided for drinking for a long time. Considering the hydrogeological setup of this region, various amelioration methods to help mitigate the ill effects of high fluoride were evaluated and better nutrition containing calcium and vitamin $\mathrm{C}$ was found to be the most effective and viable option.

Keywords. Fluorosis risk zone; exposure dose; amelioration; Odisha.

\section{Introduction}

Groundwater is a major contributor to water supply in most rural communities in India. It is commonly believed that groundwater is a safe source of potable water as it is relatively free from microbiological and inorganic chemicals' contamination and requires minimal treatment. However, in contrast, recent reports suggest that the contamination of groundwater by both geogenic and anthropogenic sources has been increasing significantly. Fluoride is one of the widespread inorganic contaminants impacting the health of people globally (Frencken 1992; Dean 1993; NRC 1993; Genxu and Guodong 2001; Chae et al. 2007; SubbaRao 2011; Jagtap et al. 2012). In humans, $\mathrm{F}^{-}$ingestion normally is through drinking water, food (Malde et al. 2011) and polluted air (Batra et al. 1995). The $\mathrm{F}^{-}$content of cultivated plants is generally low (except for tea) and contains up to 
$600 \mathrm{mg} / \mathrm{l}$ (Cao et al. 2006). However, the bioavailability of the $\mathrm{F}^{-}$in food materials is generally influenced by the mineral content of the food, e.g., certain ions can form insoluble complexes limiting the $\mathrm{F}^{-}$bioavailability (Malde et al. 2004). Studies suggest that elevated levels of fluoride in drinking water is an important factor that causes dental and skeletal fluorosis in parts of the world including India (Frencken 1992; Jacks et al. 2005; Rao et al. 2013; Bretzler and Johnson 2015; Choubisa and Choubisa 2016). It is believed that the number of persons affected by fluorosis in Asian and African countries exceeds 70 million (WHO 2006). Based on the ill effects of high fluoride on human health, the World Health Organization (WHO) has established a fluoride standard for drinking water of $1.5 \mathrm{mg} / \mathrm{l}$ (WHO 2011). Consumption of drinking water with high fluoride above the WHO limit is deemed to impact humans through dental and skeletal fluorosis. These ailments seem to be more detrimental in children as dental enamel and skeletal formation are most active during the early childhood.

There are reports that 27 out of the 30 districts of Odisha state of India are contaminated by fluoride in drinking water and this has led to acute health disorders (CGWB 2010; Nanda et al. 2011). Recent studies suggest that industrial and municipal pollution coupled with high $\mathrm{F}^{-}$in drinking water led to increasing rates of tuberculosis, cancer and other ailments in habitants of Angul district of Odisha state (Dhadse et al. 2008; Dhakate and Rao 2010; Moharana et al. 2013). It is reported that children are being affected by poor mental growth and learning disabilities apart from increasing incidences of both skeletal and dental fluorosis. The residents of the study area mostly depend on groundwater resources for drinking, which are poor in quality and causes water-borne diseases (Sahu et al. 1991). Investigations on water quality of this region reported high fluoride content (Praharaj et al. 2003; Tiwary et al. 2009; Keesari et al. 2016) and some of these studies also emphasise on the need to pre-treat the water before drinking (Moharana et al. 2013). A hydrogeochemical study was conducted by our group on the geochemistry of groundwater and the fluoride release mechanism (Keesari et al. 2016). The study inferred that $\mathrm{F}$ is mostly derived from weathered rocks and that the contribution from effluents from thermal power plants is less.

Several studies addressing water quality issues in this region were conducted; however, there are no detailed studies on the estimation of fluoride exposure to the residents through drinking water and the potential fluorosis risk zones have also not demarcated. This information is very critical to strategise effective plans for controlling the negative impacts of consumption of high fluoride on human health. The suitability of the water for irrigation was also not attempted. The major objectives of this paper are to: (i) estimate the fluoride exposure through drinking water and compare this with the allowed limits, (ii) demarcate the fluorosis risk zones and (iii) assess the water quality for drinking and irrigation in the Talchir industrial area of Angul District, Odisha.

\section{Materials and methods}

The study site falls between $20^{\circ} 52^{\prime} 30^{\prime \prime}-20^{\circ} 57^{\prime} 30^{\prime \prime} \mathrm{N}$ latitudes and $85^{\circ} 08^{\prime} 30^{\prime \prime}-85^{\circ} 14^{\prime} 30^{\prime \prime} \mathrm{E}$ longitudes covering an area of $150 \mathrm{~km}^{2}$ (figure 1). Water level depth varies from 1.26 to $13.69 \mathrm{~m}$ below ground level (bgl) and the seasonal fluctuation is 0.6 to $1.5 \mathrm{~m} \mathrm{bgl}$ (Tiwary et al. 2009). The river Mahanadi flows towards the east-southeast direction and the river Brahmani flows towards the southeast direction. The area has an average annual rainfall of $1370 \mathrm{~mm}$ and falls under the subtropic monsoon climate. The temperature typically varies between $11.9^{\circ}$ and $44.4^{\circ} \mathrm{C}$ with an average of $26.9^{\circ} \mathrm{C}$. The groundwater is extracted from the recent alluvium deposited along the river courses and at few places from deeper depths tapping weathered and fractured rocks. Dug wells extend up to $10 \mathrm{~m}$ bgl while the tube wells and bore wells tap deeper groundwater (up to $300 \mathrm{~m} \mathrm{bgl}$ ) and mostly concentrated in the Gondwana formation.

Twenty-eight groundwater samples were collected from available sources (bore wells, hand pumps and dug wells) as shown in figure 1. The sample details are given in table 1 . Water samples were filtered through $0.45 \mu \mathrm{m}$ pore size membrane filters before storing in a clean polythene bottle. Samples were acidified using conc. $\mathrm{HNO}_{3}$ to $\mathrm{pH}=2$ for cation measurements while unacidified samples were used for anion measurements. In situ parameters (temperature, $\mathrm{pH}$, dissolved oxygen (DO) and electrical conductivity (EC)) were measured by water quality kits (Corning model 313 and Orion model 130). Alkalinity was measured by Gran titration. Chemical species [anions $\left(\mathrm{Cl}^{-}, \mathrm{SO}_{4}^{2-}, \mathrm{NO}_{3}^{-}\right.$ 


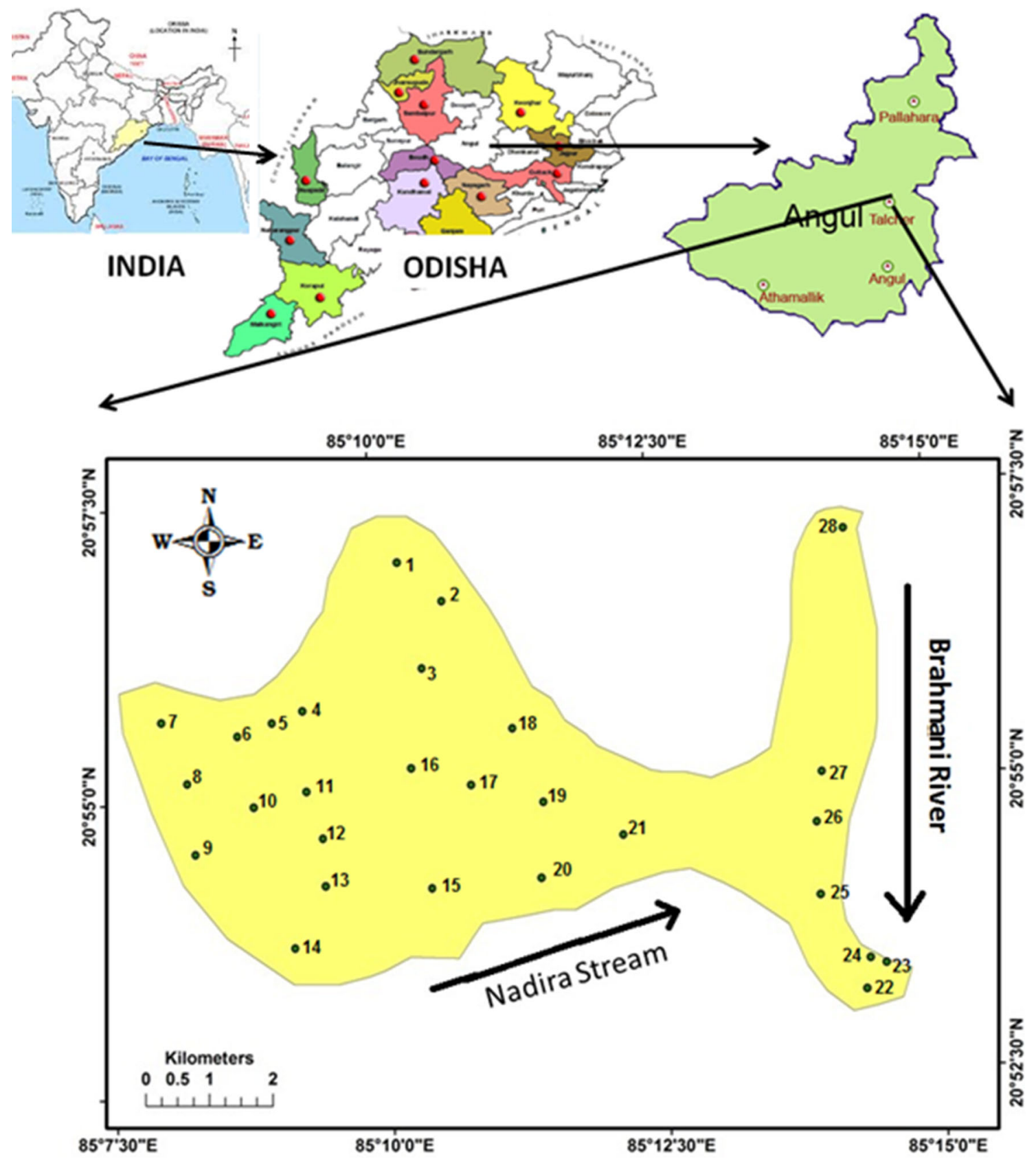

Figure 1. Sample location map.

and $\left.\mathrm{F}^{-}\right)$and cations $\left(\mathrm{Na}^{+}, \mathrm{Ca}^{2+}, \mathrm{Mg}^{2+}\right.$ and $\left.\left.\mathrm{K}^{+}\right)\right]$ were measured by ion chromatography system (Dionex DX-500). The accuracy of the chemical ion data was calculated using the charge balance equation given below and the charge balance error $(\mathrm{CBE})$ values were within the accepted limits of $\pm 5 \%$ (Hounslow 1995):

$$
\mathrm{CBE}=\frac{\text { meq }(\text { cations })-\text { meq }(\text { anions })}{\text { meq }(\text { cations })+\text { meq }(\text { anions })} \times 100 .
$$

\section{Results and discussion}

\subsection{Fluoride exposure dose}

The dissolved fluoride concentration in the study area ranges from 0.1 to $4.4 \mathrm{mg} / \mathrm{l}$ with an average of $1.2 \mathrm{mg} / \mathrm{l}$. A histogram of the fluoride distribution is shown in figure 2 . About $39 \%$ of the total samples measured (11 out of 28 samples) show $\mathrm{F}^{-}$concentration above the maximum permissible limit of $1.5 \mathrm{mg} / \mathrm{l}$ set by WHO (2011) and Bureau of Indian 


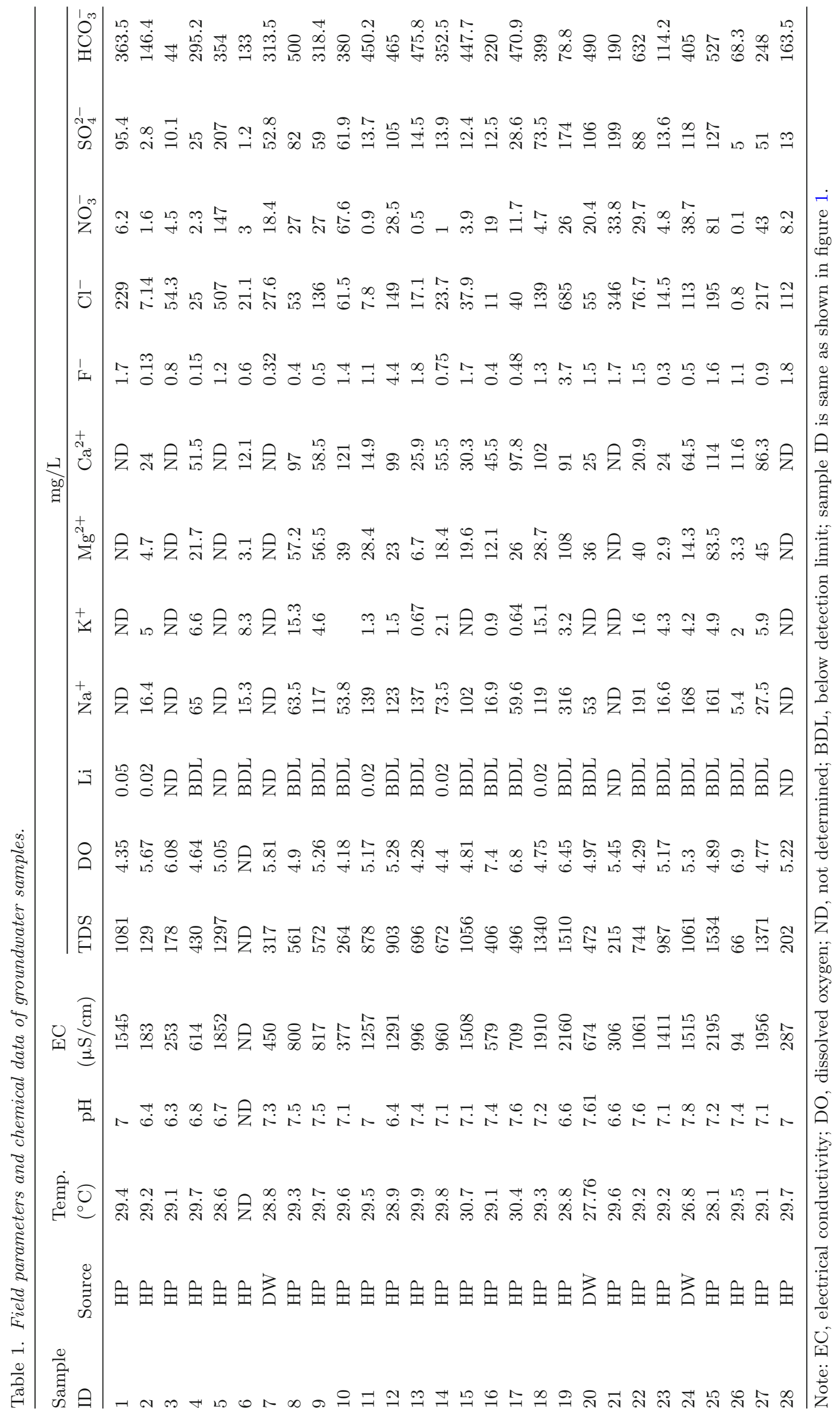




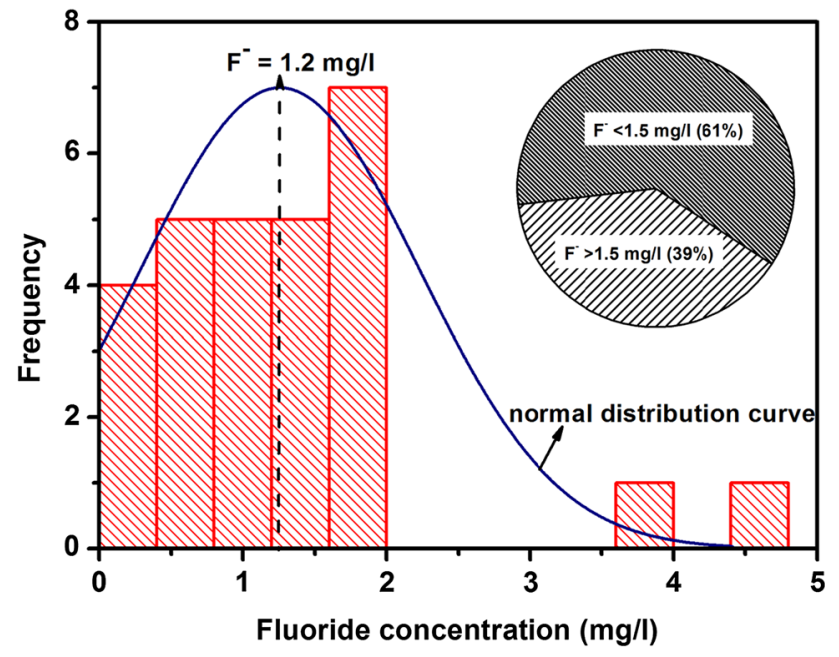

Figure 2. Histogram of the $\mathrm{F}^{-}$concentration (inset pie chart of $\%$ sample exceeding WHO limit).

Standards (BIS 2012) as shown in figure 2 (inset). Fluoride concentration up to $1.0 \mathrm{mg} / \mathrm{l}$ in potable water is considered good for skeletal and dental growth, but higher amount beyond $1.5 \mathrm{mg} / \mathrm{l}$ can result in health ailments (WHO 2011). The concentration of fluoride between 1.5 and $3.0 \mathrm{mg} / \mathrm{l}$ in drinking water results in browning and mottling of teeth, which is an initial manifestation of dental fluorosis and this further leads to hard and brittle teeth. $\mathrm{F}^{-}$level between 4 and $8 \mathrm{mg} / \mathrm{l}$ results in skeletal fluorosis, which further develops into crippling fluorosis when the $\mathrm{F}^{-}$level rises above $10 \mathrm{mg} / \mathrm{l}$. Excessive $\mathrm{F}^{-}$ingestion has other health effects such as urinary tract malfunction, muscle fibre degeneration, gastrointestinal problems, red blood cell deformities, reduced immunity and neurological manifestations (Lian-Fang and Jian-Zhong 1995; Fordyce et al. 2007; Shailaja and Johnson 2007; Davies 2008; WHO 2011; Chen et al. 2012).

The fluoride exposure dose was calculated for humans (infants, children and adults) based on the following equation (Jha et al. 2009):

$$
\text { Exposure dose }=\frac{C \times \mathrm{WI}}{\mathrm{BW}},
$$

where $C$ is the total bioavailable fluoride concentration $(\mathrm{mg} / \mathrm{l})$ in groundwater, WI is the water intake $(\mathrm{l} / \mathrm{d})$ and $\mathrm{BW}$ is the body weight $(\mathrm{kg})$. In this case, the dose was calculated by assuming exposure is chronic and the total dissolved fluoride represents the total bioavailable fluoride (Jackson et al. 2002). It was also assumed that groundwater is the only

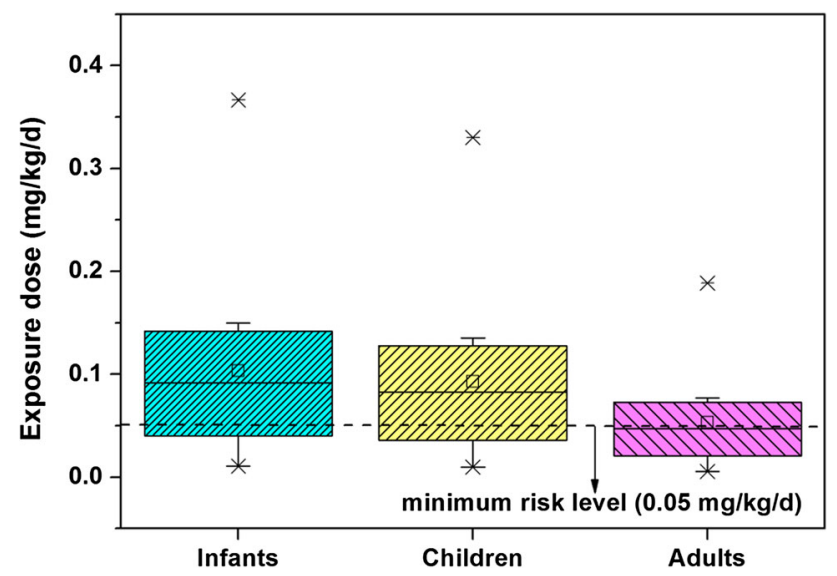

Figure 3. Fluoride exposure dose to residents of this region.

source of drinking for the residents of this area; however, packaged water is also used for drinking in some instances. Water intake for different ages of humans was taken as $0.25,1.5$ and $3 \mathrm{l} / \mathrm{d}$ for infants (6 kg body weight), children (20 kg body weight) and adults (70 kg body weight), respectively (Brindha et al. 2016). The concentration of fluoride was doubled in the case of infants taking into account boiling of water for milk preparation (Grimaldo et al. 1995).

A Box-Whisker plot of the exposure doses of fluoride for three age groups, adults, children and infants, is given in figure 3. An estimated level for minimum risk $(0.05 \mathrm{mg} / \mathrm{kg} / \mathrm{d})$ by Agency for Toxic Substances and Diseases Registry (Levy 1994; ATSDR 2003) was also given in figure 3. The median value of the exposure dose for adults was at par with the minimum risk level while for children and infants the median values exceed that of the minimum risk level. Even though the daily ingested total $\mathrm{F}^{-}$through food is not considered in this study, the exposure dose of $\mathrm{F}^{-}$ based on water intake alone shows that groundwater consumption by residents in this area can lead to fluorosis. The risk exposure is found to be about two times higher for infant and children compared to the adults (table 2). The true estimate considering the fluoride ingestion through vegetables, fruits and prepared food would be higher than the calculated one. On the other hand, other sources of drinking water such as packaged water or treated groundwater by conventional techniques such as osmosis or filtration reduce the fluoride exposure.

The maximum values of exposure doses for different age groups in this area are comparable to other fluorosis affected regions such as Nalgonda, India 
Table 2. Exposure dose and risk exposure in different ages.

\begin{tabular}{llcc}
\hline & Infant & Child & Adult \\
\hline Body weight (kg) (Jha et al. 2009) & 6 & 20 & 70 \\
$\mathrm{~F}^{-}$in water (average; figure 3) & 1.2 & 1.2 & 1.2 \\
Water intake (1/d) (Brindha et al. 2016) & 0.25 & 1.5 & 3 \\
Exposure dose (ED) (mg/kg/d) & 0.10 & 0.09 & 0.05 \\
Standard (STD) (mg/kg/d) (Levy 1994) & 0.05 & 0.05 & 0.05 \\
Risk exposure (ED/STD) & 2.1 & 1.9 & 1.1 \\
\hline
\end{tabular}
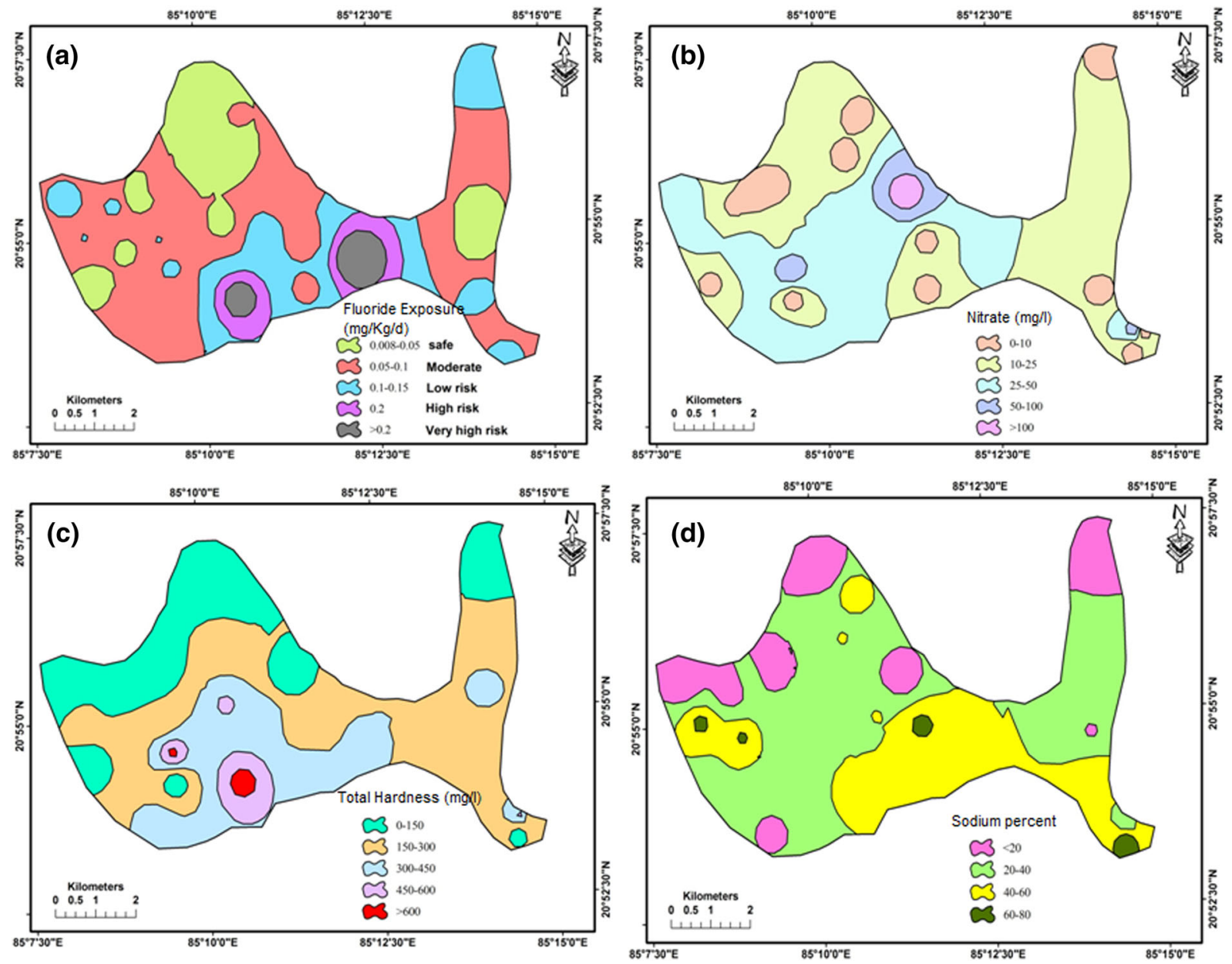

Figure 4. Spatial distribution of (a) fluoride exposure to the public through drinking water, (b) nitrate concentration (mg/l), (c) total hardness $(\mathrm{mg} / \mathrm{l})$ and $(\mathbf{d})$ sodium per cent of groundwater samples.

(Brindha and Elango 2013), Pambar basin, Tamil Nadu (Kalpana and Elango 2013), Vaniyar basin, Tamil Nadu (Jagadeshan et al. 2015), Dindigul district of Tamil Nadu (Viswanathan et al. 2009), Bushehr province in southern Iran (Battaleb-Looie et al. 2013) and others. A fluoride risk map is shown in figure 4(a). An average value of $\mathrm{F}^{-}$exposure to different age groups was used for contouring purpose. It can be seen from the figure that the southern part of the study area has the maximum fluoride exposure risk to the residents of this region.
However, with the exception of some western and northwestern parts, the entire study area is prone to fluorosis.

\subsection{Suitability of other parameters to drinking purpose}

The major ion and physical parameter data of groundwater samples is shown by Box-Whisker plots (figure 5a-1). Most of the parameters showed a narrow distribution in groundwater. No extreme 

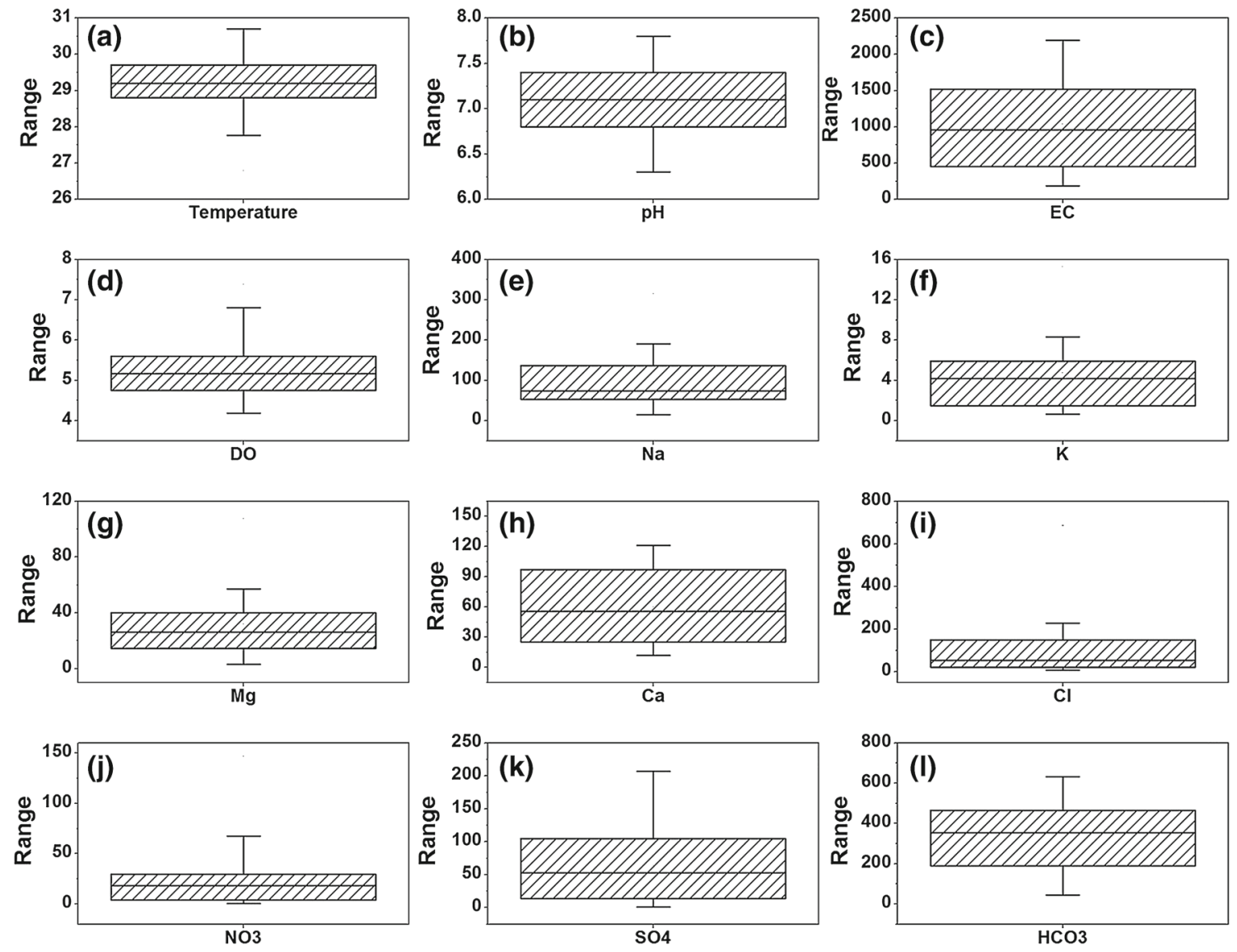

Figure 5. Box-Whisker plot of physicochemical and chemical parameters: (a) temperature $\left({ }^{\circ} \mathrm{C}\right),(\mathbf{b}) \mathrm{pH},(\mathbf{c}) \mathrm{EC},(\mathbf{d}) \mathrm{DO}$, (e) sodium, (f) potassium, (g) magnesium, (h) calcium, (i) chloride, (j) nitrate, (k) sulphate and (l) bicarbonate. All concentrations are expressed in $\mathrm{mg} / \mathrm{l}$ except temperature, $\mathrm{pH}$ and $\mathrm{EC}(\mu \mathrm{S} / \mathrm{cm})$.

values for physical or chemical parameters were noticed in this region indicating that the overall chemistry of the groundwater is uniform throughout the study region. The basic water types were found to be $\mathrm{Na}-\mathrm{Ca}-\mathrm{HCO}_{3}, \mathrm{Na}-\mathrm{Mg}-\mathrm{HCO}_{3}$, Ca$\mathrm{Mg}-\mathrm{HCO}_{3}$ and $\mathrm{Ca}-\mathrm{Na}-\mathrm{HCO}_{3}$. A detailed hydrochemical interpretation on facies variation and fluoride release mechanism has been given in Keesari et al. (2016).

The hydrochemical parameters of groundwater were checked for suitability for domestic purposes based on the recommendations by WHO (2011) and BIS (2012). The average values of different water quality parameters are within the permissible limits as per WHO and BIS, whereas individual samples have shown higher concentrations than the prescribed limits (table 3). Most of the samples show ion concentration within the WHO guideline values (figure 5a-1). Only a few samples show $\mathrm{pH}$, total dissolved solids (TDS), $\mathrm{Mg}^{2+}, \mathrm{Cl}^{-}$and $\mathrm{NO}_{3}^{-}$concentrations above the WHO guideline values (figure $5 \mathrm{~b}, \mathrm{c}, \mathrm{g}$, i and $\mathrm{j}$ ).
Potassium is an essential nutrient that is critical to the functioning of nerve and muscle cells, which if taken in excess may cause hyperkalaemia or hypokalaemia if one is deficient in $\mathrm{K}^{+}$. No permissible limit has been suggested for this ion in groundwater by WHO; however, the European Community (EU 1980) has issued a guideline value of $10 \mathrm{mg} / \mathrm{l}$ and maximum admissible level of $12 \mathrm{mg} / \mathrm{l}$. Two samples showed $\mathrm{K}^{+}$concentration above prescribed drinking water limits (figure $5 \mathrm{f}$ ). Nitrate is soluble and leaches through soil along with the infiltrating water. Common sources for high nitrate are decaying organic matter, domestic wastes (David and Gentry 2000) and fertilisers (Tripathi et al. 2000). Consumption of water with high nitrate in potable water can lead to methemoglobinemia (blue baby syndrome) in infants. Groundwater of this area contains nitrate in the range of $0.5-147 \mathrm{mg} / \mathrm{l}$ and $11 \%$ of the samples show contamination (table 3 and figure $5 \mathrm{j}$ ). The contour diagram of nitrate in groundwater suggests that the nitrate contamination $(>45 \mathrm{mg} / \mathrm{l})$ was noticed only at a few locations (figure $4 \mathrm{~b}$ ). 


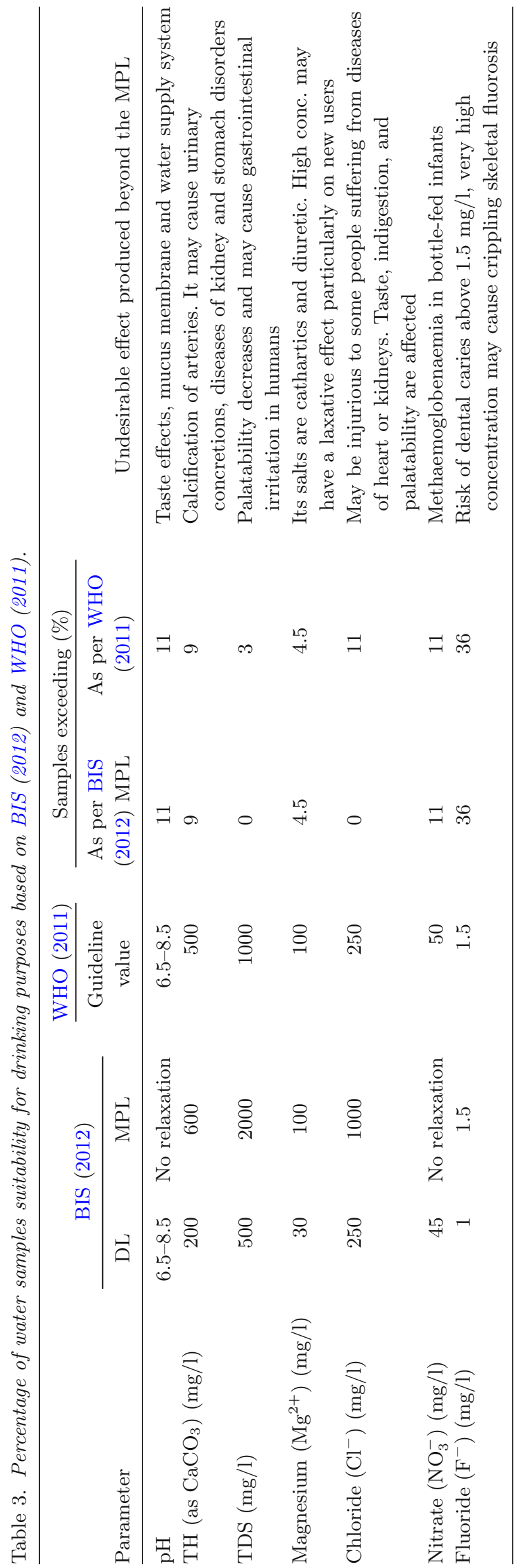

TDS and total hardness (TH) are common indicators to determine the suitability of water for drinking. High TDS in drinking water causes gastrointestinal irritation and laxative effects in humans while high TH may raise the risk of calcification in arteries and also kidney or bladder or stomach disorders. The TDS values in groundwater of this region range between 129 and 1534 $\mathrm{mg} / \mathrm{l}$. The water classification based on TDS values (Davies and DeWiest 1966) is given in table 3. It can be seen from the table that $43 \%$ of the samples are desirable, $29 \%$ of samples are permissible and the rest is unfit for drinking.

Total hardness is caused by dissolved salts of $\mathrm{Ca}^{2+}, \mathrm{Mg}^{2+}$ or $\mathrm{Fe}$ and is expressed as $\mathrm{mg} / \mathrm{l}$ of $\mathrm{CaCO}_{3}$. It is calculated by the equation given by Todd (1980):

$$
\mathrm{TH}=2.497 \times \mathrm{Ca}^{2+}+4.115 \times \mathrm{Mg}^{2+},
$$

where $\mathrm{Mg}^{2+}$ and $\mathrm{Ca}^{2+}$ concentrations are in equivalents per million. The $\mathrm{TH}$ values in groundwater samples are in the range of $43-672 \mathrm{mg} / \mathrm{l}$. Based on the classification suggested by Durfor and Becker (1964), 9\% fall in soft category, $13 \%$ each for moderately hard and hard types whereas the remaining $65 \%$ samples fall under the very hard type of water (table 4). The TH contour map is shown in figure $4(\mathrm{c})$.

\subsection{Suitability to irrigation}

To evaluate the irrigation suitability of groundwater EC, sodium adsorption ratio (SAR), per cent of sodium (Na\%), residual sodium carbonate (RSC), Wilcox diagram and United States Salinity Laboratory (USSL) classification were commonly employed. The high amount of sodium in water used for irrigation impacts the soil permeability and its texture in such a way that soil becomes hard to plough and seedling emergence becomes difficult (Trivedy and Goel 1984). SAR is normally used to quantify the sodium/alkali hazard in a given water sample. Another major concern with high $\mathrm{Na}^{+}$in irrigation water is ion exchange with the alkaline earth metals in soil/clay material. This eventually results in soil with poor internal drainage (Karanth 1987).

The SAR value of a given water sample is calculated using the equation given by Richards (1954):

$$
\mathrm{SAR}=\frac{\mathrm{Na}^{+}}{\sqrt{\mathrm{Ca}^{+2}+\mathrm{Mg}^{+2} / 2}},
$$


Table 4. Water classification based on TDS and TH.

\begin{tabular}{|c|c|c|c|c|c|}
\hline TDS & Water classification & $\begin{array}{c}\text { Samples } \\
(\%)\end{array}$ & $\begin{array}{c}\text { Total } \\
\text { hardness }\end{array}$ & $\begin{array}{c}\text { Water } \\
\text { classification }\end{array}$ & $\begin{array}{c}\text { Samples } \\
(\%)\end{array}$ \\
\hline Up to 500 & Desirable for drinking & 43 & Up to 60 & Soft & 9 \\
\hline $500-1000$ & Permissible for drinking & 29 & $60-120$ & Moderately hard & 13 \\
\hline $1000-3000$ & Useful for irrigation & 29 & $120-180$ & Hard & 13 \\
\hline$>3000$ & Unfit for drinking and irrigation & 0 & $>180$ & Very hard & 65 \\
\hline
\end{tabular}

Table 5. Water class based on irrigation suitability.

\begin{tabular}{|c|c|c|}
\hline $\mathrm{EC}(\mu \mathrm{S} / \mathrm{cm})$ & Water class & Samples (\%) \\
\hline$<250$ & Excellent & 6.90 \\
\hline $250-750$ & Good & 37.93 \\
\hline $750-2000$ & Permissible & 48.28 \\
\hline $2000-3000$ & Doubtful & 6.90 \\
\hline$>3000$ & Unsuitable & 0.00 \\
\hline \multicolumn{3}{|c|}{ Alkalinity hazard (SAR) } \\
\hline$<10$ & Excellent & 100 \\
\hline $10-18$ & Good & - \\
\hline $18-26$ & Doubtful & - \\
\hline$>26$ & Unsuitable & - \\
\hline \multicolumn{3}{|c|}{ Per cent sodium } \\
\hline$<20$ & Excellent & 13.79 \\
\hline $20-40$ & Good & 37.93 \\
\hline $40-60$ & Permissible & 34.48 \\
\hline $60-80$ & Doubtful & 13.79 \\
\hline$>80$ & Unsafe & - \\
\hline \multicolumn{3}{|c|}{ Residual sodium carbonate } \\
\hline$<1.25$ & Good & 51.72 \\
\hline $1.25-2.5$ & Doubtful & 24.14 \\
\hline$>2.5$ & Unsuitable & 24.14 \\
\hline
\end{tabular}

where the concentrations are in equivalents per million. The SAR values of the groundwater samples of the study area range from 0.5 to 6.2 and belong to low sodium hazard class (table 5 ).

$\mathrm{Na} \%$ is another parameter used for assessing the suitability of water for irrigation (Wilcox 1948). Sodium ions present in water samples complexes with $\mathrm{HCO}_{3}^{-}$and $\mathrm{CO}_{3}^{2-}$ to form alkaline soils, and combine with chloride to form saline soils. Both these soils are not favourable for plant growth. Na\% is calculated using the following equation:

$$
\mathrm{Na} \%=\frac{\left(\mathrm{Na}^{+}+\mathrm{K}^{+}\right) \times 100}{\mathrm{Ca}^{2+}+\mathrm{Mg}^{2+}+\mathrm{Na}^{+}+\mathrm{K}^{+}} .
$$

All the concentrations are in milliequivalents per litre. Na\% up to 60 is allowed for agricultural purposes (Ramakrishna 1998). Groundwater of this

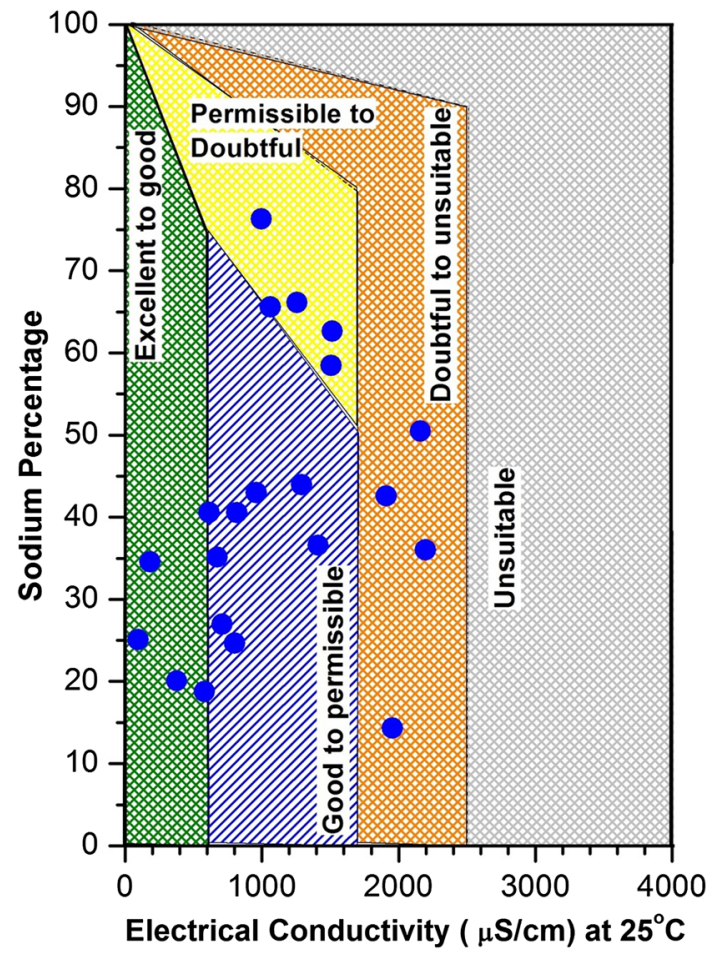

Figure 6. Irrigational suitability of groundwater in the study area (Wilcox diagram).

study area has $\mathrm{Na} \%$ in the range of $14.3-76.3 \%$ and four samples show Na\% above $60 \%$ value (table 5). The spatial distribution of $\mathrm{Na} \%$ is shown in figure $4(\mathrm{~d})$. In addition to poor drainage of the soils, high $\mathrm{Na} \%$ in water along with high EC renders reduction in the osmotic activity of plants and limits the absorption of water and nutrients from the soil. In order to visualize the combined effect of both EC and $\mathrm{Na} \%$, a diagram proposed by Wilcox (1955) is constructed and shown in figure 6 . The majority of the groundwater samples are suitable for irrigation purposes whereas some samples fall in under permissible to doubtful (5) and doubtful to unsuitable (2) categories (figure 6).

The high alkalinity of groundwater $\left(\mathrm{HCO}_{3}^{-}\right.$and $\mathrm{CO}_{3}^{2-}$ ) allows the formation of precipitates with $\mathrm{Ca}^{2+}$ and $\mathrm{Mg}^{2+}$ and makes the water unsuitable 


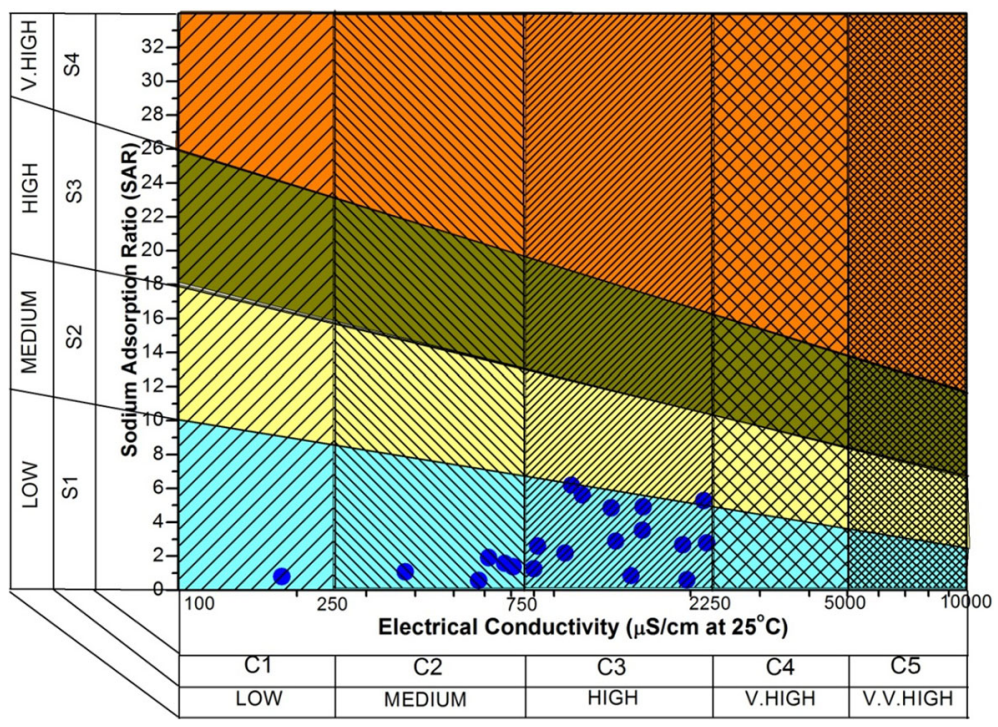

Figure 7. USSL classification of groundwater in the study area.

for irrigation. RSC is used to quantify this effect and is calculated by the equation given by Eaton (1950):

$$
\mathrm{RSC}=\left(\mathrm{HCO}_{3}^{-}+\mathrm{CO}_{3}^{2-}\right)-\left(\mathrm{Ca}^{2+}+\mathrm{Mg}^{2+}\right)
$$

Water containing RSC less than 1.25 is suitable for irrigation whereas marginally suitable with RSC up to 2.5 and not suitable for irrigation above 2.5 (Lloyd and Heathcote 1985). The RSC values of the groundwater samples of this area range from -12.3 to 6.0. Groundwater samples fall under good category $(51 \%)$ and an equal per cent of samples (49\%) also fall in doubtful and unsuitable categories (table 5). USSL diagram (USSL 1954) was employed to further evaluate the irrigational suitability of the groundwater. As per USSL classification, low-salinity water $(<250 \mu \mathrm{S} / \mathrm{cm})$ can be used for all types of soils. In the study area, the majority of the groundwater samples fall into two zones, C2S1 and C3S1, representing medium-to-high salinity and low alkalinity water, respectively (figure 7 ). These zones indicate that water can be used for irrigation on almost all types of soils with little danger of exchangeable sodium.

\subsection{Possible remedial measures}

Inorganic ions such as arsenic, fluoride, lead, nitrate, selenium and uranium are considered as the key chemicals responsible for large-scale health effects through drinking water exposure, therefore providing guidance on identifying local priorities and implementing proper management is very essential for tackling these chemicals in drinking water (WHO 2004, 2011). There are four broad approaches suggested by WHO to limit the negative effects of $\mathrm{F}^{-}$on public health (WHO 2002). These approaches were evaluated for the current study area considering the hydrogeological constraints (figure 8).

The first approach is the identification of an alternative source of potable water with low fluoride content. In this area, the groundwater is being pumped from the semi-consolidated and consolidated formations and the well yields are less than $100 \mathrm{~m}^{3}$ /d signifying moderate-to-low yielding wells (http://www.indiawaterportal.org) and the fluoride content is also higher in these formations (up to $1.5-5 \mathrm{mg} / \mathrm{l}$ ) (Nanda et al. 2011; NEERI 2016). Nearby river and other surface water bodies are also moderately contaminated by fluoride (Keesari et al. 2016), hence providing an alternate water source for drinking is not a viable option in this case.

The second approach is to dilute high fluoride water with low fluoride water to attain a mass balance of within $1.5 \mathrm{mg} / \mathrm{l}$. The groundwater resources capacity in the study area fell below $3000 \mathrm{HaM}$, which is very low (http://www.india waterportal.org); in addition, the amount of the low $\mathrm{F}^{-}$groundwater available is not sufficient and also contains high nitrate concentration (figure 4b). The overall groundwater yields are quite low $(\sim 5 \mathrm{lps})$. The rainfall in the study area is low 


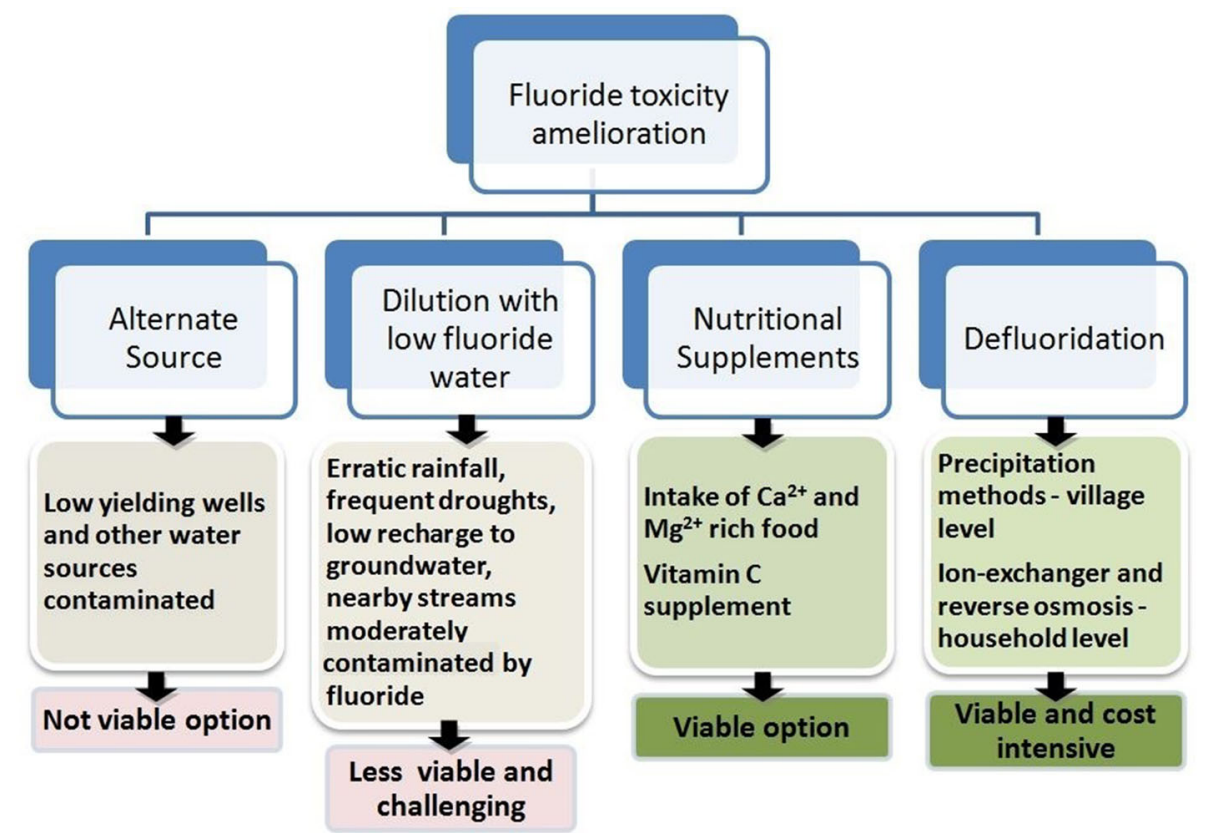

Figure 8. Flowchart depicting the suitable strategies for amelioration of fluoride toxicity.

and erratic and therefore frequently results in drought conditions (http://www.angul.nic.in/atla s_of_development_trends_angul.pdf). Due to complex subsurface and geomorphological constraints, the rainfall recharge to groundwater is also low (http://www.indiawaterportal.org). These factors reflect that dilution of high $\mathrm{F}^{-}$waters would be a challenging and difficult task.

The third approach involves improving the dietary condition of the residents. This aspect mostly takes into consideration the socioeconomic status of the residents. Good nutrition is suggested to combat the impact of fluorosis on the residents as it helps in reducing the absorption of $\mathrm{F}^{-}$in the body tissues (http://www.medindia.net/patients/ patientinfo/fluorosis.htm). Studies on nutritional interventions for fluorosis mitigation have shown that a diet containing low $\mathrm{Ca}^{2+}$ increases the retention of $\mathrm{F}^{-}$in the body (http://www.inrem.in /fluorosis/pdf/nutrition.pdf). On the other hand, $\mathrm{Mg}^{2+}$ helps in the excretion of $\mathrm{F}$ through urine. Consumption of vitamin $\mathrm{C}$ was found to increase the ejection of $\mathrm{F}^{-}$and reduce the severity of fluorosis. A closer examination of the total hardness contour $\left(\mathrm{Ca}^{2+}+\mathrm{Mg}^{2+}\right)$ of this region (figure 4c) shows that high fluorosis risk zones typically coincide with the high TH zones. This can be a positive indication, as nutritional studies have shown that $\mathrm{Ca}^{2+}$ and $\mathrm{Mg}^{2+}$ help in reducing the risk of fluorosis to the residents. Supplementing the diet with vitamin $\mathrm{C}$, which is very widely available in the area, can further help in reducing the incidences of fluorosis (Mehta Dhaval and Shah 2013). The fourth approach is fluoride removal using various ion exchange and adsorption techniques. This needs initiation from the governmental and non-governmental institutions so that households are supplied with $\mathrm{F}^{-}$removal filters depending on the amount of the $\mathrm{F}^{-}$present in the groundwater at a location. A combination of proper nutrition and installation of fluoride removal kits can together effectively improve the health condition of the residents of this region and other similar regions elsewhere.

\section{Summary and conclusions}

Groundwater quality and its suitability for drinking with a special emphasis on $\mathrm{F}^{-}$exposure to humans was evaluated in the Talcher Area, Odisha. An assessment of groundwater suitability for irrigation purposes was also presented in this paper. This study is significant as the water resources are being polluted by mining and other industrial activities in this region and groundwater is impacted by geogenic contamination like high fluoride concentration. Results indicate that most of the hydrochemical parameters are well within the WHO guideline values except fluoride. Indicators such as SAR, RSC and Na\% that qualify the water for irrigation suitability are found to be 
under low sodium hazard and permissible category. There are also cases of water samples falling under doubtful to unfit category due to the presence of high sodium concentrations.

The $\mathrm{F}^{-}$concentration in the study is found to be in the range of $0.1-4.4 \mathrm{mg} / \mathrm{l}$. About $39 \%$ of the samples show fluoride concentration above the WHO and BIS permissible limit of $1.5 \mathrm{mg} / \mathrm{l}$. The exposure dose for $\mathrm{F}^{-}$due to drinking water was found to be in the range of $0.01-0.37,0.01-0.33$ and $0.01-0.19$ $\mathrm{mg} / \mathrm{kg} / \mathrm{d}$ for infants, children and adults, respectively. The $\mathrm{F}^{-}$exposure values fall close to or above the minimum risk level for fluorosis. The spatial trends of the $\mathrm{F}^{-}$exposure estimates indicate that the western and northwestern parts of the study area show no or less risk of fluorosis, while in rest of the study area, the fluorosis risk is moderate to high. The presence of higher concentrations of dissolved $\mathrm{Ca}^{2+}$ and $\mathrm{Mg}^{2+}$ in zones of high fluoride risk present a favourable case to prevent the severity of the fluorosis. However, incorporation of vitamin $\mathrm{C}$ in the diet as well as use of $\mathrm{F}^{-}$removal kits can effectively reduce the risk of fluorosis among the residents of this area.

\section{Acknowledgements}

The authors sincerely thank the Talcher Power Plant authorities and colleagues from Isotope Hydrology Section, BARC, for their support during sampling. Shri K S S Sarma, Head, Isotope and Radiation Application Division, BARC, is gratefully acknowledged.

\section{References}

ATSDR 2003 Toxicological profile for fluorides, hydrogen fluoride, and fluorine; US Department of Health and Human Services, Public Health Service, Agency for Toxic Substances and Disease Registry, Atlanta, GA, 404p.

Batra J, Vispute J B, Deshmukh A N and Vali S 1995 Contribution from rock, soil and ground water to fluoride content of food stuffs grown in some selected villages of Bhadravati Tehsil, Chandrapur District, Maharashtra; Fluoride Environ. Nagpur, India: Gondwana Geol. Soc. 9 81-90.

Battaleb-Looie S, Moore F, Malde M K and Jacks G 2013 Fluoride in groundwater, dates and wheat: Estimated exposure dose in the population of Bushehr, Iran; Food Compos. Anal. 29(2) 94-99.

BIS 2012 Bureau of Indian Standards, drinking water specification (2nd revision) ICS 13.060.20, IS 10500:2012.

Bretzler A and Johnson C A 2015 The geogenic contamination handbook: Addressing arsenic and fluoride in drinking water; Appl. Geochem. 63 642-646.
Brindha K and Elango L 2013 Geochemistry of fluoride rich groundwater in a weathered granitic rock region, Southern India; Water Qual. Expo. Health 5(3) 127138.

Brindha K, Jagadeshan G, Kalpana L and Elango L 2016 Fluoride in weathered rock aquifers of southern India: Managed aquifer recharge for mitigation; Environ. Sci. Pollut. Res. 23(9) 8302-8316.

Cao J, Zhao Y, Li Y, Deng H J, Yi J and Liu J W 2006 Fluoride levels in various black tea commodities: Measurement and safety evaluation; Food Chem. Toxicol. 44(7) 11311137.

CGWB 2010 Ground water quality in shallow aquifers of India; Central Ground Water Board, Ministry of Water Resources, Government of India, Faridabad (http://admin.indiaenvironmentportal.org.in/files/ GW_Quality_in_shallow_aquifers.pdf).

Chae G T, Yun S T, Mayer B, Kim K H, Kim S Y, Kwon J S, Kim K and Koh Y K 2007 Fluorine geochemistry in bedrock groundwater of South Korea; Sci. Total Environ. 385(1) 272-283.

Chen Q, Song Z, Lu Q, Wang M, Feng J, Tian H, Liu J, Li X and Zhang R 2012 Fluorine contents and its characteristics of groundwater in fluorosis area in Laizhou Bay, China; Toxicol. Environ. Chem. 94(8) 14901501.

Choubisa S L and Choubisa D 2016 Status of industrial fluoride pollution and its diverse adverse health effects in man and domestic animals in India; Environ. Sci. Pollut. Res. 23(8) $7244-7254$.

David M B and Gentry L E 2000 Anthropogenic inputs of nitrogen and phosphorus and riverine export for Illinois, USA; J. Environ. Qual. 29(2) 494-508.

Davies T C 2008 Environmental health impacts of East African Rift volcanism; Environ. Geochem. Health 30(4) 325-338.

Davies S N and DeWiest R J M 1966 Hydrogeology; Wiley, New York.

Dean 1993 Health effects of ingested fluoride; National Academy of Sciences, Washington, USA, 169p.

Dhadse S, Kumari P and Bhagia L J 2008 Fly ash characterization, utilization and Government initiatives in India - A review; J. Sci. Ind. Res. 67 11-18.

Dhakate R and Rao T G 2010 Assessment of groundwater quality in Talcher coalfield area, Orissa, India; Int. J. Earth Sci. Eng. 3(1) 43-55.

Durfor C N and Becker E 1964 Public water supplies of the 100 largest cities in the United States, 1962 (No. 1812); US Government Printing Office, pp. 343-346.

Eaton F M 1950 Significance of carbonates in irrigation waters; Soil Sci. 69(2) 123-134.

EU Directive C 1980 European union council directive $80 / 778 /$ EEC of 15 July 1980 relating to the quality of water intended for human consumption; Off. J. Eur. Commun. L229 11-29.

Fordyce F M, Vrana K, Zhovinsky E, Povoroznuk V, Toth G, Hope B C, Iljinsky U and Baker J 2007 A health risk assessment for fluoride in Central Europe; Environ. Geochem. Health 29(2) 83-102.

Frencken J E 1992 Endemic fluorosis in developing countries: Causes, effects and possible solutions; TNO Institute for Preventive Health Care. Publ. No. 91.082, Leiden. 
Genxu W and Guodong C 2001 Fluoride distribution in water and the governing factors of environment in arid north-west China; J. Arid Environ. 49(3) 601-614.

Grimaldo M, Borja-Aburto V H, Ramírez A L, Ponce M, Rosas M and Díaz-Barriga F 1995 Endemic fluorosis in San Luis Potosí, Mexico; Environ. Res. 68 25-30.

Hounslow A W 1995 Water quality data analysis and interpretation; CRC Press, Florida.

Jacks G, Bhattacharya P, Chaudhary V and Singh K P 2005 Controls on the genesis of some high-fluoride groundwaters in India; Appl. Geochem. 20(2) 221-228.

Jackson P J, Harvey P W and Young W F 2002 Chemistry and bioavailability aspects of fluoride in drinking water; Report No.: CO 5037 (http://americanfluoridationsociety. org/wp-content/uploads/2016/05/Jackson-lead-corrosivewrcreport.pdf).

Jagadeshan G, Kalpana L and Elango L 2015 Major ion signatures for identification of geochemical reactions responsible for release of fluoride from geogenic sources to groundwater and associated risk in Vaniyar River basin, Dharmapuri district, Tamil Nadu, India; Environ. Earth Sci. 74(3) 2439-2450.

Jagtap S, Yenkie M K, Labhsetwar N and Rayalu S 2012 Fluoride in drinking water and defluoridation of water; Chem. Rev. 112(4) 2454-2466.

Jha S K, Nayak A K and Sharma Y K 2009 Fluoride occurrence and assessment of exposure dose of fluoride in shallow aquifers of Makur, Unnao district, Uttar Pradesh, India; Environ. Monit. Assess. 156(1-4) 561-566.

Kalpana L and Elango L 2013 Assessment of groundwater quality for drinking and irrigation purposes in Pambar river sub-basin, Tamil Nadu; Indian J. Environ. Prot. 33(1) 1-8.

Karanth K R 1987 Groundwater assessment, development and management; Tata-McGraw-Hill, New Delhi.

Keesari T, Sinha U K, Deodhar A, Krishna S H, Ansari A, Mohokar H and Dash A 2016 High fluoride in groundwater of an industrialized area of Eastern India (Odisha): Inferences from geochemical and isotopic investigation; Environ. Earth Sci. 75(14) 1-17.

Levy S M 1994 Review of fluoride exposures and ingestion; Commun. Dent. Oral Epidemiol. 22(3) 173-180.

Lian-Fang W and Jian-Zhong H 1995 Outline of control practice of endemic fluorosis in China; Social Sci. Med. 41(8) 1191-1195.

Lloyd J W and Heathcote J A A 1985 Natural inorganic hydrochemistry in relation to ground water; Clarendon, Oxford, 294p.

Malde M K, Zerihun L, Julshamn K and Bjorvatn K 2004 Fluoride, calcium and magnesium intake in children living in a high-fluoride area in Ethiopia. Intake through food; Int. J. Paediat. Dent. 14(3) 167-174.

Malde M K, Scheidegger R, Julshamn K and Bader H P 2011 Substance flow analysis: A case study of fluoride exposure through food and beverages in young children living in Ethiopia; Environ. Health Perspect. 119(4) 579584.

Mehta Dhaval N and Shah J 2013 Reversal of dental fluorosis: A clinical study; J. Nat. Sci. Biol. Med. 4(1) 138-144.

Moharana J K, Nanda P M and Garnaik B K 2013 Eutrofication due to industrialization in Angul-Talcher industrial complex of Odisha; Int. J. Sci. Environ. Technol. 2 20-27.
Nanda P M, Garnaik B K and Panda S 2011 Studies on Fluoride pollution in ground water of Angul-Talcher industrial complex of Odisha; Asian J. Chem. Environ. Res. 4(1) 13-16.

NEERI 2016 Integrated hydrogeological, geophysical, hydrochemical and groundwater flow and solute transport modelling studies around the ash filled South Balanda Mine voids in Angul district, Odisha (Undertaken During 2012-2016), http://environmentclearance.nic.in/writerea ddata/modification/Extension/Attach_file/23112016FCA Y0QHUAnnexure-HydrogeologyReport-NEERI.pdf.

NRC 1993 Health effects of ingested fluoride; National Research Council, National Academy Press, Washington DC.

Praharaj T, Tripathy S, Powell M A and Hart B R 2003 Geochemical studies to delineate topsoil contamination around an ash pond of a coal-based thermal power plant in India; Environ. Geol. 45(1) 86-97.

Ramakrishna 1998 Groundwater; Handbook, India.

Richards L A 1954 Diagnosis and improvement of saline and alkali soils; In: US Department of Agriculture, Agri. Hand book 60, Washington 78(2) 154 .

Sahu B K, Panda R B, Sinha B K and Nayak A 1991 Water quality index of the River Brahmani at Rourkela industrial complex of Orissa; J. Ecotoxicol. Environ. Monit. 1(3) 169-175.

Shailaja K and Johnson M E C 2007 Fluorides in groundwater and its impact on health; J. Environ. Biol. 28 331-332.

SubbaRao N 2011 High-fluoride groundwater; Environ. Monit. Assess. 176(1) 637-645.

Rao N S, Subrahmanyam A and Rao G B 2013 Fluoridebearing groundwater in Gummanampadu sub-basin, Guntur district, Andhra Pradesh, India; Environ. Earth Sci. 70(2) 575-586.

Tiwary R K, Dhakate R, Sinha A and Singh V S 2009 Evaluation of impact of mining on groundwater resources in Talcher Coalfield, India; Int. J. Earth Sci. Eng. 2(3) 238 252.

Todd D K 1980 Ground water hydrology; Wiley, New York.

Tripathi S D, Aravindakshan P K, Ayyappan S, Jena J K, Muduli H K, Chandra S and Pani K C I 2000 New high in crop production in India through intensive polyculture; J. Aquat. Trop. 15(2) 119-128.

Trivedy R K and Goel P K 1984 Chemical and biological methods for water pollution studies; Environmental Publication, Karad.

USSL 1954 Diagnosis and improvement of saline and alkaline soils; United States Salinity Laboratory, U.S. Department of Agriculture, Washington.

Viswanathan G, Jaswanth A and Gopalakrishnan S 2009 Mapping of fluoride endemic areas and assessment of fluoride exposure; Sci. Tot. Environ. 407(5) 15791587.

WHO 2002 Fluorides, environmental health criteria 227; International Programme on Chemical Safety, Geneva.

WHO 2004 Guidelines for drinking water quality (3rd edn); World Health Organization, Geneva.

WHO 2006 Guidelines for drinking-water quality (3rd edn), 1st addendum to Vol. 1, Recommendations, Geneva, 595 .

WHO 2011 Guidelines for drinking water quality; 4th edn, WHO Press, 20 Avenue Appia, Geneva, Switzerland. 
Wilcox L V 1948 The quality of water for irrigation use; Vol. 962, U.S. Dept. of Agriculture, Tech, Bull, Washington, DC, 40p.

Corresponding editor: ABhiJit MukherJeE
Wilcox L V 1955 Classification and use of irrigation water; Vol. 969, U.S. Geological department, Agri. Arc., Washington, DC, 19p. 